\title{
Micropropagation of Leucaena leucocephala from in vitro cultured shoot tip explants
}

\author{
V. K. Gautam, Nidhi Gautam \\ Department of Botany, Deen Dayal Upadhyaya College, Daulat Ram College, Delhi University, Delhi
}

\begin{abstract}
Multiple shoots have been produced from shoot tip explants excised from in vivo grown plants on MS + BA medium. These shoots produced multiple roots when subcultured on a fresh MS medium containing IAA. The browning of explants was inhibited using polyvinylpyrrolidone which is supposed to absorb polyphenols as the main cause of browning of explants.
\end{abstract}

Keywords: Callusing, Multiple shoots, Polyvinylpyrrolidone, Shoot tips

\section{INTRODUCTION}

Forests are the best source of renewable energy and also provide raw materials for several important industries. Among leguminous trees are of special interest from an ecological point of view, since many of them can readily fix atmospheric nitrogen. Therefore, it is essential to improve our fabaceous forest trees using tissue culture techniques and present plant biotechnological approaches. The application of tissue culture techniques offers novel and quick means of improving trees over the conventional time-consuming breeding methods. In addition to that, height of trees and long life put further hindrance. The genetically superior trees with fast growth rate can be rapidly multiplied through micropropagation. Mascarenhas and Muralidharan (1989) have summarized the work on tissue culture studies of forest trees in India. The first report of tissue culture using shoot tip cultures of a leguminous tree was published by Skolmen and Maps (1976) in Acacia koa. In their studies, shoots were regenerated from shoot tip derived callus though at a very low frequency. From literature survey, it has been noticed that leguminous trees are very recalcitrant for in vitro differentiation. However, there are some positive reports where regeneration has been achieved using juvenile explants excised from in vitro grown young seedlings, for example, Albizia lebbeck (Gharyal and Maheshwari, 1983), Dalbergia sissoo (Mukhopadhyaya and Ram, 1981), Acacia nilotica (Mathur and Chandra, 1983), Leucaena leucocephala (Datta and Datta, 1985; Dhawan and Bhojwani, 1985), Dalbergia latifolia (LakshmiSita et al., 1986), and Sesbania bispinosa (Kapoor and Gupta, 1986). There are very few reports on clonal propagation using explants, excised from field grown mature plants. In these studies, either axillary buds from nodes or apical buds have responded well, for example, in Prosopis cineraria (Goyal and Arya, 1984), Albizia procera
(Ror and Datta, 1985), L. leucocephala (Datta and Datta, 1985), and D. latifolia (LakshmiSita et al., 1986).

\section{MATERIALS AND METHODS}

Seeds of Leucaena were obtained from Pratap Nursery, Dehradun, and were sown in the Botanical Garden of the Department, Delhi University. Young shoots $2-3 \mathrm{~cm}$ were excised from 5-year-old trees of Leucaena growing in botanical garden. Shoot pieces were washed with tap water several times and finally surfaced sterilized with chlorine water in the culture room inside a laminar flow cabinet for 10-20 min. Subsequently, they were washed thrice with sterilized distilled water (2-3 min each) to remove all traces of chlorine. Later, just $2-3 \mathrm{~mm}$ long shoot tips containing 3-4 leaf primordia were excised from sterilized twigs. All steps from surface sterilization to inoculation were carried out under sterile conditions in a laminar flow placed in the culture room. MS (Murashige and Skoog, 1962), NB (Nitsch, 1969), and $\mathrm{B}_{5}$ (Gamborg et al., 1968) basal as well as supplemented with various phytohormones (BA, IAA, and NAA) were used. All media contained 3\% sucrose (BDH) and $0.8 \%$ agar (Difco-Bacto). The $\mathrm{pH}$ of all media was adjusted to 5.8 before autoclaving. Approximately $20 \mathrm{ml}$ of the medium was poured into each culture tube and finally autoclaved using standard parameters. All cultures were maintained in the culture room

DOI: $10.30954 / 2319-5169.2 .2020 .3$

Submission: $24-08-2020$

Received: 04-09-2020

Acceptence: $19-10-2020$

Published: 27-12-2020

${ }^{*}$ Corresponding author: V. K. Gautam, Department of Botany, Deen Dayal Upadhyaya College, Daulat Ram College, Delhi University, Delhi. E-mail: vkgautam2001@gmail.com 
at $25^{\circ} \mathrm{C}$ temperature and $50-60 \%$ relative humidity under continuous cool white light tubes (approx. 500 lux; Philips, India). Observations were taken on various aspects such as initial number of explant inoculated and total number survived, total number of explants callusing and rooting, size, amount, color and texture of calli on relative basis, the number of shoots and roots per explant, and initiation of multiple shoots and their number per explant. To prevent browning of the explant, polyvinylpyrrolidone (PVP) was used at 250-1000 mg/1.

\section{Observations}

Initial cultures of shoot tips [Figure $1 \mathrm{a}$ and b] on $\mathrm{MS}, \mathrm{B}_{5}$, and NB basal as well as phytohormones supplemented media resulted in callus as well as shoot development (Table 1; Figure 1c). The highest percentage of callusing (35) was achieved on NB $+2.25 \mathrm{mg} / \mathrm{l} \mathrm{BA}$. The explants cultured on various media mentioned in Table 1, produced single shoots at low frequency (2-6\%). Later, these responding explants after subculturing on MS + BA (3 mg/l) + NAA $(0.05 \mathrm{mg} / \mathrm{l})$, formed

Table 1: Morphogenic response of shoot tip explants excised from in vivo grown plants of Leucaena leucocephala on various media for 72 days

\begin{tabular}{lccc}
\hline Hormone mg/l & Survived & $\begin{array}{c}\text { Callusing } \\
\mathbf{( \% )}\end{array}$ & $\begin{array}{c}\text { Shooting } \\
(\mathbf{\%})\end{array}$ \\
\hline B $_{5}$ (control) & 47 & 13 & 4 \\
B $_{5}+0.17$ IAA & 46 & 4 & 2 \\
NB (control) & 24 & 0 & 0 \\
NB + 2.25 BA & 23 & 35 & 4 \\
NB + 1.75 IAA & 22 & 5 & 5 \\
MS (control) & 18 & 6 & 0 \\
MS +1 BA & 18 & 0 & 0 \\
MS + 3 BA +0.05 NAA & 18 & 17 & 6 \\
MS + 1 IAA & 18 & 6 & 0 \\
MS + 1 NAA & 17 & 0 & 0 \\
\hline
\end{tabular}

multiple shoots [Figure 2a] within 3-4 weeks of subculturing. In most of the cultures, the differentiation of shoots was generally preceded by callusing [Figure $2 \mathrm{~b}$ ]. The callus developed either from entire surface of the explant or from its cut end and subsequently differentiated numerous shoots. Further, proliferation and multiplication of differentiated shoots continued to increase in repeated subcultures raised after every 3-4 weeks on fresh medium of the same composition [Figure 3a]. The maximum number of shoots obtained per explant was 6 in each subculture. When the well-developed shoots with 4 or 5 nodes and internodes were transferred to MS medium containing IAA ( $1 \mathrm{mg} / \mathrm{l})$, after about 4 weeks, a few shoots developed roots at their basal ends [Figure 3b].

The browning of initial shoot tip cultures was also observed after 3-4 days of inoculation. Therefore, in subsequent experiments, PVP (PVP; at 250-1000 mg/l) was added in the medium. 250 and $500 \mathrm{mg} / 1 \mathrm{PVP}$ inhibited explant browning up to 3-4 weeks and also increased the frequency of green healthy shoots.

\section{RESULTS AND DISCUSSION}

In vitro regeneration leading to plantlet formation is difficult in tree species (Bonga, 1977), plantlets have been obtained in L. leucocephala from shoot tip explants excised from field grown plants during present investigations. These results are of interest since leguminous trees are strongly recalcitrant to in vitro morphogenesis. Among cytokinins, BA is most effective for shoot differentiation in Leucaena. At $3 \mathrm{mg} / \mathrm{l}$, BA produced multiple shoots in the presence of $0.05 \mathrm{mg} / 1 \mathrm{NAA}$. The regeneration using explants from in vivo growing trees is important for clonal propagation of selected elite species. Therefore, shoot tip, stem and leaf pieces were excised and cultured on different media. Out of various explants, shoot tips were found more responsive. In previous reports, micropropagation of Leucaena from mature trees has been

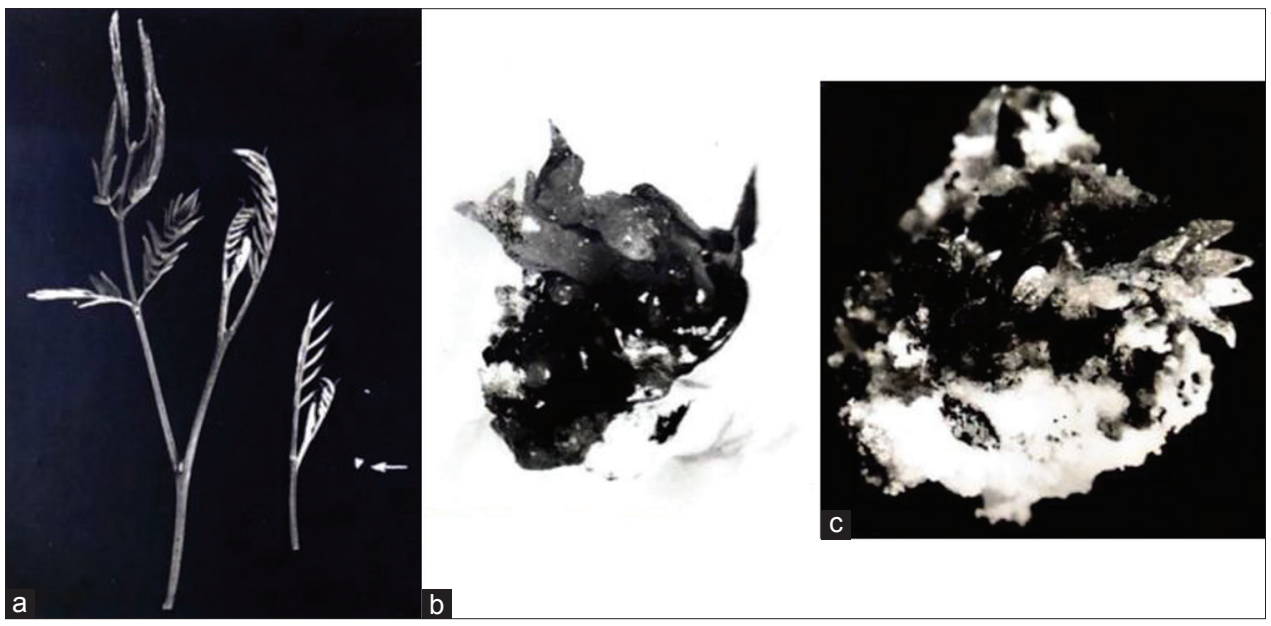

Figure 1: Morphogenic response of shoot tip explants excised from in vivo grown old trees. (a) Young twigs from 5-year-old trees along with a small explant (arrow) $\times 1$. (b) Swollen shoot tip after 12 weeks on B basal medium $\times 3.5$. (c) Differentiation of shoot buds from callus cultured on $\mathrm{MS}+3 \mathrm{mg} / \mathrm{l}+0.05 \mathrm{mg} / \mathrm{l} \mathrm{NAA} \times 4$ 

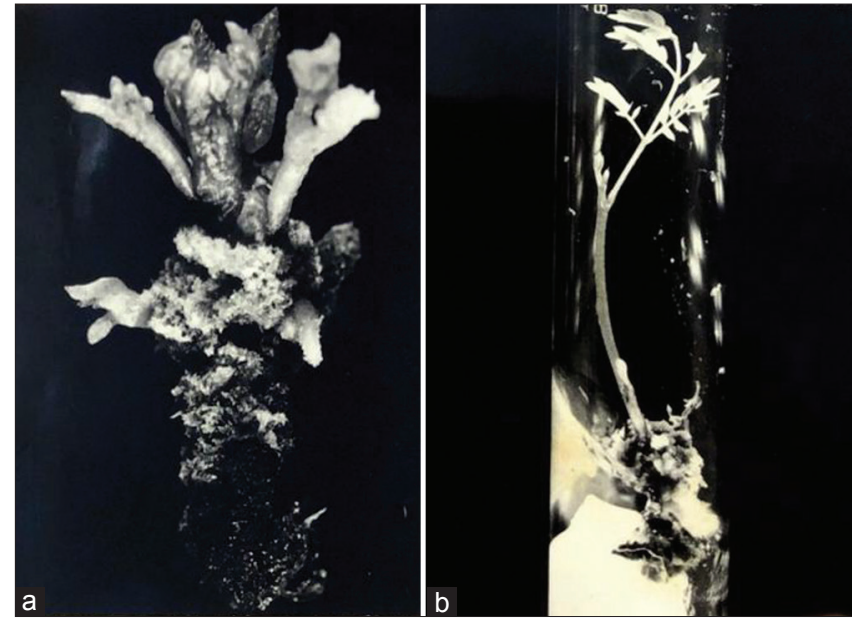

Figure 2: Morphogenic response of shoot tip explants. (a) Multiple shoot formations from callusing shoot tip on MS + $3 \mathrm{mg} / \mathrm{l} \mathrm{BA}+0.05 \mathrm{mg} / 1 \mathrm{NAA} \times 4$. (b) An elongated shoot on the same medium after 104 days of inoculation $\times 1.1$
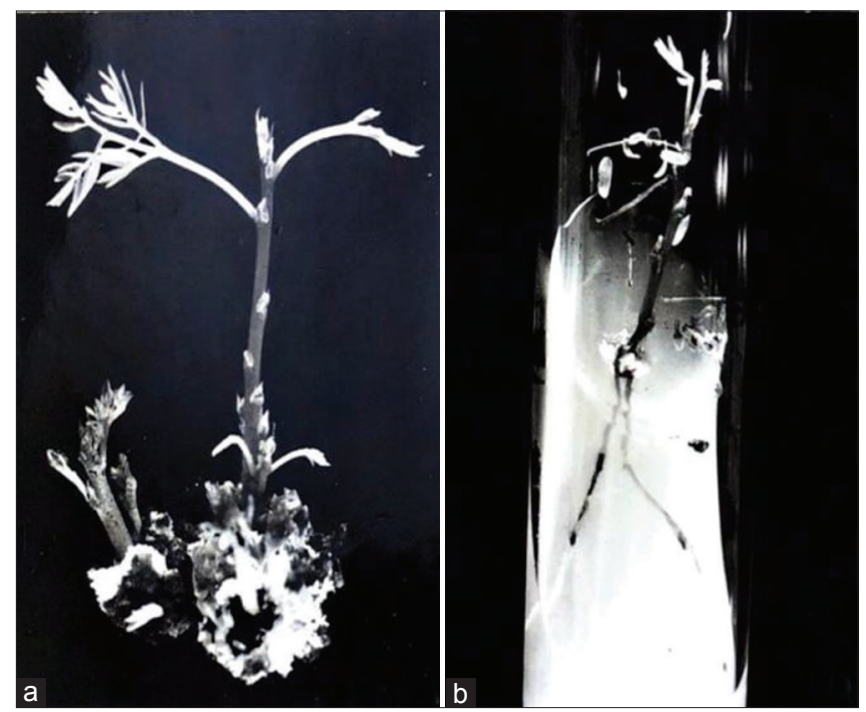

Figure 3: Multiplication and proliferation of shoots and rhizogenesis. (a) Young shoots on MS $+3 \mathrm{mg} / \mathrm{l} \mathrm{BA}+0.05 \mathrm{mg} / \mathrm{l}$ NAA for the next 4 weeks $\times 3.7$. (b) Formation of roots after subculturing for 27 days on MS $+1 \mathrm{mg} / \mathrm{IAA} \times 1.5$

achieved but it was through axillary bud cultures (Datta and Datta, 1985; Dhawan and Bhojwani, 1985). Similar to our results with Leucaena, shoots have been obtained from shoot tips of mature trees of $A$. procera on MS + BA medium (Ror and Datta, 1985). Rooting of regenerated shoots in woody species is believed to be difficult (Nemeth, 1986). In D. latifolia, Sankara Rao (1986) developed a long three-step culture procedure to induce rooting in regenerated shoots. However, in Leucaena, excised shoots could be rooted after transferring them to IAA supplemented medium. Like the present observations, excised shoots of D. latifolia (LakshmiSita et al., 1986) and A. lebbeck (Gharyal and Maheshwari, 1983) were also rooted in the presence of IAA. Thus, it is possible to micropropagate
Leucaena mature trees. Regeneration of plantlets from old trees is of great importance since the phenotype of selected plants and their desirability is known (LakshmiSita et al., 1986) Among leguminous trees, multiple shoots have been obtained from nodal explants of 30-year-old trees of D. sissoo (Datta et al., 1983). One of the major problems in culturing old tree explants like shoot tips was the leaching out of high amount of brown substances believed to be polyphenols from tissues in the medium. PVP at 250 and $500 \mathrm{mg} / \mathrm{l}$ was quite effective in checking browning of shoot tip explants excised from old trees. This ultimately led to the development of plantlets in vitro.

\section{CONCLUSION}

A rapid and efficient method of clonal propagation and micropropagation has been established in L. leucocephala using shoot tip explants excised from mature trees. Multiple shoots can be differentiated on MS + BA medium. Differentiated and well-developed shoots could be rooted on subculturing them on IAA containing fresh medium.

\section{Financial Support and Sponsorship}

Nil.

\section{Conflicts of Interest}

The authors declare that there is no conflict of interest in this work.

\section{REFERENCES}

Bonga, J.M. 1977. Applications of tissue culture in forestry. In: Reinert, J. and Bajaj, Y.P.S., editors. Applied and Fundamental Aspects of Plant Cell, Tissue and Organ Culture. SpringerVerlag, Berlin. pp. 93-108.

Datta, K. and Datta, S.K. 1985. Auxin+ Kno3 induced regeneration of leguminous tree-Leucaena leucocephala through tissue culture. Curr. Sci., 54, 248-250.

Datta, S.K. and Datta, K. 1983. Auxin induced regeneration of forest tree-Dalbergia sissoo Roxb. through tissue culture. Curr. Sci., 52, 434-436.

Datta, S.K., Datta, K. and Pramanik, T. 1983. In vitro clonal multiplication of mature trees of Dalbergia sissoo Roxb. Plant Cell Tissue Organ Cult., 2, 15-20.

Dhawan, V. and Bhojwani, S.S. 1985. In vitro vegetative propagation of Leucaena leucocephala (Lam.) de Wit. Plant Cell Rep., 4, 315-318.

Gamborg, O.L., Miller, R.A. and Ojima, K. 1968. Nutrient requirements of suspension cultures of soybean root cells. Exp. Cell Res., 50, 151-158.

Gharyal, P.K. and Maheshwari, S.C. 1983. In vitro differentiation of plantlets from tissue cultures of Albizzia lebbeck L. Plant Cell Tissue organ Cult., 2, 49-53.

Goyal, Y. and Arya, H.C. 1984. Tissue culture of desert trees: I. Clonal multiplication of Prosopis cineraria by bud culture. $J$. Plant Physiol., 115, 183-189.

Kapoor, S. and Gupta, S.C. 1986. Rapid in vitro differentiation of Sesbania bispinosa plants-a leguminous shrub. Plant Cell 
Tissue Organ Cult., 7, 263-268.

LakshmiSita, G., Chattopadhyay, S. and Tejavathi, H.D. 1986. Plant regeneration from shoot callus of rosewood (Dalbergia latifolia Roxb.). Plant Cell Rep., 5, 266-268.

Mascarenhas, A.F. and Muralidharan, E.M. 1989. Tissue culture of forest trees in India. Curr. Sci., 58, 606-613.

Mathur, I. and Chandra, N. 1983. Induced regeneration in stem explants of Acacia nilotica. Curr. Sci., 52, 882-883.

Mukhopadhyay, A. and Ram, H.Y.M. 1981. Regeneration of plantlets from excised roots of Dalbergia sissoo. Indian J. Exp. Biol., 19, 1113-1115.

Murashige, T. and Skoog, F. 1962. A revised medium for rapid growth and bioassays with tobacco tissue cultures. Physiol. Plant, 15, 473-497.

Nemeth, G. 1986. Induction of rooting. In: Bajaj, Y.P.S., editor. Biotechnology in Agriculture and Forestry. Vol. 1. Springer-
Verlag, Berlin. pp. 49-64.

Nitsch, J.P. 1969. Experimental androgenesis in Nicotiana. Phytomorphology, 19, 389-404.

Roy, S.K. and Datta, S.K. 1985. Clonal propagation of a legume tree Albizia procera through tissue culture. Bangladesh J. Bot., 14, 127-131.

Sankara Rao, K. 1986. Plantlets from somatic callus tissue of the east Indian rosewood (Dalbergia latifolia Roxb.) Pl. Cell Rep., 3, 199-201.

Skolmen, R.G. and Mapes, M.O. 1976. Acacia koa Gray plantlets from somatic callus tissue. J. Hered., 67, 114-115.

How to cite this article: Gautam VK, Gautam N. Micropropagation of Leucaena leucocephala from in vitro cultured shoot tip explants.

Int. J. Bioinform. Biol. Sci. 8(2), 11-14. 